Linha D'Água (Online), São Paulo, v. 29, n. 1, p. 143-165, jun. 2016

\title{
ESCRITAS DA MEMÓRIA: AUTORIA E IDENTIDADE CULTURAL
}

\section{WRITTEN MEMORY: AUTHORSHIP AND CULTURAL IDENTITY}

\author{
Norma Seltzer Goldstein* e Francesco Antonio Capo** \\ Universidade de São Paulo, São Paulo, SP, Brasil
}

Resumo: Este artigo retoma pesquisa ainda em desenvolvimento sobre a relação entre escritas da memória, discurso e identidade cultural. A escolha do tema apoia-se na ideia de que memória, identidade e sentimento de pertença se relacionam intrinsecamente. 0 espaço da memória é também 0 espaço da ressignificaçã̃o: 0 espaço de construir e reconstruir representaçōes e identidades. Construímos representações do passado de acordo com as representaçocoes que fazemos do presente, e tanto umas quanto as outras são atravessadas pelas representacọ̃es social e historicamente construídas. Tais concepcọoes associam-se cos conceitos de autonomia (FRElRE, 2002), agência (BAZERMAN, 2011; KLEIMAN, 2006) e autoria (BAZERMAN, 2011).

Palavras-chave: Memória; Discurso; Identidade; Autoria; Agência.

\begin{abstract}
This article is based on a research work in progress which approaches the relationship between written from memory, discourse and cultural identity. This choice rests on the idea that memory, identity and sense of belonging are intrinsically related. The memory space is also the space of the "ressignification": the space where we construct and reconstruct representations and identities. We build representations of the past according to the representations we make of the present, and both are contaminated by representations socially and historically constructed. Such concepts are associated with the concepts of autonomy (FREIRE, 2002), agency (BAZERMAN, 2011; KLEIMAN, 2006) and authorship (BAZERMAN, 2011).
\end{abstract}

Keywords: Memory; Discourse; Identity; Authorship; Agency.

* Professora da Universidade de São Paulo - USP, São Paulo, SP, Brasil; ngolds@uol.com.br ** Mestrando do Programa de Pós-graduação PROFLETRAS - Mestrado Profissional em Rede Nacional, da Universidade de São Paulo - USP, São Paulo, SP, Brasil; francescoacapo@ig.com.br 
Linha D'Água (Online), São Paulo, v. 29, n. 1, p. 143-165, jun. 2016

\section{Introdução}

Este artigo retoma parcialmente a pesquisa que vem sendo realizada desde o início de 2015, como requisito para a obtenção do título de Mestre Profissional em Letras. Seguiremos o seguinte percurso: a primeira seção, intitulada "Memória e letramento", faz a apresentação da pesquisa: objetivos, organização, metodologia, hipóteses teóricas que a justificam, além de relato da sequência didática aplicada; a segunda e a terceira seções, intituladas "Memória e identidade" e "Escritas da memória e autoria", desenvolvem, a partir da análise de resultados ainda parciais, algumas reflexões sobre as relações entre memória, identidade sociocultural e autoria; na conclusão, reflete-se acerca da importância deste estudo no que se refere ao aprimoramento das práticas pedagógicas, sobretudo na Educação de Jovens e Adultos.

\section{Memória e letramento}

A pesquisa elegeu como objeto de estudo a relação entre escritas da memória, letramento, identidade cultural e autoria. Pretendeu-se verificar até que ponto a prática pedagógica com escritas da memória contribui para o letramento de adultos oriundos de culturais orais que tiveram pouco contato com a palavra escrita. O ponto de partida foi a suposição de que o trabalho com as escritas da memória propiciaria o sentimento de pertencimento e, por conseguinte, levaria o aluno a construir uma imagem de si mesmo como sujeito-autor de sua escrita, passando a compreendê-la como prática social significativa. Nossa hipótese foi que a palavra escrita transformada em discurso da memória levaria o aluno a se apropriar dessa escrita, uma vez que ela refletiria sua identidade pessoal e também coletiva. Segundo Michael Pollack apud Sousa (s/d),

Podemos, portanto, dizer que a memória é um elemento constituinte do sentimento de identidade, tanto individual como coletiva, na medida em que ela é também um fator extremamente importante do sentimento de continuidade e de coerência de uma pessoa ou de um grupo em sua reconstrução de si (...). (POLLACK, M., 1992, p. 200-212 apud SOUSA, op. cit., p. 7)

Com efeito, ao relembrarmos o passado, confrontamos valores, crenças e sentimentos do presente com valores, crenças e sentimentos do passado. Vozes, imagens, sons, cheiros, o passado nos assalta, e ressignificamos sentidos há muito perdidos. O espaço da memória é também o espaço da ressignificação, do reenraizamento: o espaço de construir e reconstruir representações e identidades. Conforme Hall (2006) apud Sousa (op cit.): "A identidade torna-se uma 'celebração 
Linha D'Água (Online), São Paulo, v. 29, n. 1, p. 143-165, jun. 2016

móvel': formada e transformada continuamente em relação às formas pelas quais somos representados ou interpelados nos sistemas culturais que nos rodeiam." (HALL, S. 2006, p. 12-13 apud SOUSA, op. cit., p. 8).

Acrescente-se o conceito de "memória coletiva", de Halbwachs. Segundo Bosi (1987):

(...) Halbwachs não vai estudar a memória como tal, mas os "quadros sociais da memória”. Nessa linha de pesquisa, as relações a serem determinadas já não ficarão adstritas ao mundo da pessoa (relações entre o corpo e o espírito, por exemplo), mas perseguirão a realidade interpessoal das instituições sociais. (BOSI, 1987, p. 54)

Ao lembrarmos o passado, carregamos conosco valores, crenças e sentimentos coletivos. Em outras palavras, construímos representações do passado de acordo com as representações que fazemos do presente, e tanto umas quanto as outras são atravessadas pelas representações social e historicamente construídas. Ainda de acordo com Bosi (1987),

(...) A lembrança é uma imagem construída pelos materiais que estão, agora, à nossa disposição, no conjunto de representações que povoam nossa consciência atual. Por mais nítida que pareça a lembrança de um fato antigo, ela não é a mesma imagem que experimentamos na infância, porque nós não somos os mesmos de então e porque nossa percepção alterou-se e, com ela, nossas ideias, nossos juízos de realidade e de valor. (BOSI, op. cit., p. 55)

Há como que um liame ou entrecruzamento de representações, a partir do qual forjamos uma identidade que é individual e ao mesmo tempo coletiva. De acordo com Woodward (2000) apud Sousa (op. cit): "A representação inclui as práticas de significação e os sistemas simbólicos por meio dos quais os significados são produzidos, posicionando-nos como sujeito"(WOODWARD, Kathryn. 2000, p. 17 apud SOUSA, op. cit., p. 6). Ao nos sentirmos pertencentes a um passado e a um presente, sentimo-nos também integrantes de uma cultura, de uma maneira de representar o mundo. Há, portanto, uma profunda relação entre memória, linguagem e identidade.

A decisão de trabalhar com escritas da memória, além de justificar-se pela necessidade de resgatar a autoestima dos alunos (sem a qual o processo ensino -aprendizagem não se dá de forma eficiente), também reflete a constatação de que "ensinar a ler e escrever a grupos de tradição oral tem dimensões identitárias, 
Linha D'Água (Online), São Paulo, v. 29, n. 1, p. 143-165, jun. 2016

uma vez que envolve a aculturação desses grupos por meio da escrita; aprender a ler e escrever envolve a aprendizagem de práticas discursivas de grupos aos quais o aprendiz não pertence" (KLEIMAN, 2006, p. 82). Ou seja, mais do que resgatar a autoestima do aluno, pretendíamos que ele se fizesse agente da própria voz. Ainda segundo Kleiman (2006), “(...) no processo concreto de mobilização dos recursos do grupo de alunos para a ação via práticas letradas, repousaria a autonomia de um grupo que, fora da sala de aula, é sempre subalterno e silenciado" (KLEIMAN, op. cit, p. 85). De fato, quando o sujeito se torna agente de sua própria fala, ele se faz e se refaz com e pela palavra. Nesse movimento, ele negocia significados e se insere como agente nas relações de poder que se consubstanciam na e pela palavra.

A palavra escrita, assim concebida, não é objeto exterior, pertencente ao outro, como uma prótese que o teimoso organismo rejeitasse. A palavra escrita, dessa maneira, é compreendida como prática social significativa, uma prática de letramento, tal como a compreende Street (2014): “O conceito de 'práticas de letramento' se coloca num nível mais alto de abstração e se refere igualmente ao comportamento e às conceitualizações sociais e culturais que conferem sentido aos usos da leitura e/ou da escrita" (STREET, 2014, p. 18).

Aquele que faz da palavra escrita sua experiência revivida por meio do discurso ressignifica a prática letrada, reconceitualiza-a, porquanto a palavra escrita lhe pertence e, ao mesmo tempo, ele é pertencido por ela. Tal noção associa-se aos conceitos de autonomia (FREIRE, 2002), agência (BAZERMAN, 2011; KLEIMAN, 2006) e autoria (BAZERMAN, 2011), visto que, ao escrever sua memória, o indivíduo constitui-se como sujeito de sua própria escrita, é um sujeito-autor, e sua escrita se insere em uma trama de outras escritas de outros sujeitos-autores. Se a palavra escrita, assim compreendida, constrói a história, esse sujeito-autor se constitui como agente histórico.

Previmos que esta pesquisa se desenvolveria em três etapas, em paralelo com a pesquisa teórica. Primeiramente, a aplicação de sequência didática, que abordaria o gênero textual "autobiografia" (e gêneros afins, como o "relato autobiográfico" e o "romance autobiográfico") e suas especificidades (aspectos discursivos, pragmáticos, linguísticos, composicionais, estilísticos e histórico-sociais). As discussões acerca desse gênero textual seriam realizadas a partir de leituras de excertos do romance Menino de Engenho, de José Lins do Rego, embora outros textos pudessem ser utilizados. Em segundo lugar, a coleta de dados: textos escritos pelos alunos; fichas de acompanhamento do processo ensino-aprendizagem; questionários de perfil sócio-econômico e cultural respondidos pelos alunos. Por fim, a análise qualitativa dos dados coletados. No momento, estamos na terceira etapa do percurso. 
Linha D'Água (Online), São Paulo, v. 29, n. 1, p. 143-165, jun. 2016

Ou seja, a sequência didática já foi planejada e aplicada e os resultados estão sendo analisados qualitativamente.

A sequência didática, constituída por 16 aulas, foi aplicada de março a outubro de 2015, em uma turma de $4^{\circ}$ módulo (equivalente aos $8^{\circ}$ e $9^{\circ}$ anos do Ensino Fundamental), da modalidade de ensino EJA (Educação de Jovens e Adultos), no CIEJA (Centro Integrado de Educação de Jovens e Adultos) Ermelino Matarazzo, bairro da zona leste da capital paulista. Trata-se de turma de 16 alunos adultos de 30 a 60 anos, com rendimento mensal entre 1 a 3 salários mínimos, a maior parte deles trabalhadores braçais (pedreiros, ajudantes de pedreiro, atendentes de pequenas unidades comerciais, como lojas de roupa e açougues, empregadas domésticas diaristas, mecânicos de automóveis), oriundos do meio rural (em sua maior parte, de pequenas cidades do Nordeste $)^{1}$, que tinham pouco contato com a palavra escrita, conforme se constatou por meio atividade diagnóstica realizada no início do ano letivo.

Ao longo da sequência didática, foram realizadas atividades de leitura e de produção textual. Algumas leituras motivaram discussões sobre o tema "memória e identidade"; outras, o exame de aspectos composicionais, estilísticos e temáticos relacionados ao gênero em estudo, sobretudo no que diz respeito às tipologias textuais ${ }^{2}$ : sequências narrativas, descritivas e dialogais. As atividades de produção textual foram desenvolvidas em quatro etapas: motivação, produção inicial, reescrita orientada e elaboração da versão final do texto. As atividades de reescrita foram acompanhadas e orientadas pelo professor. Durante as atividades, os alunos utilizaram dicionários e muitas vezes uns auxiliaram os outros. $\mathrm{O}$ professor fazia correções indicativas (sem apresentar soluções) a lápis ou fazia sugestões oralmente, questionava o sentido de frases ou palavras, pedia aos alunos que explicassem

1 Essas informações se baseiam em pesquisa realizada pela unidade escolar no início deste ano.

2 Sobre a abordagem dos "tipos textuais", tomam-se aqui como base os conceitos de Werlich (1973) apud Marcuschi (2010), in: DIONISIO, Angela Paiva; MACHADO, Anna Rachel; BEZERRA, Maria Auxiliadora (orgs.) Gêneros textuais \& ensino. São Paulo: Parábola, 2010, pp. 19-38. Segundo tal conceito, os tipos textuais são sequências caracterizadas pela natureza linguística de sua composição (aspectos lexicais, sintáticos, morfossintáticos, relações lógicas etc.). Conforme tal pressuposto, os tipos textuais são: injunção, narração, argumentação, exposição/explicação, descrição e diálogo. Assim, os gêneros dizem respeito ao uso da língua em situações comunicativas, variando a forma e estrutura composicional conforme as condições de produção. Já os tipos textuais remetem à materialidade linguística, aos aspectos intralinguísticos, ou seja, à forma como o gênero se materializa linguisticamente. Assim, cada gênero textual articula os tipos textuais de maneira particular, consoante suas características composicionais e estilísticas. 
determinadas sequências, sempre de modo a respeitar a autonomia do aluno em seu processo de aprendizagem e de acordo com o nível de aquisição de habilidades de escrita de cada um. Assim, evitou-se, de um lado, o excesso de intervenções no texto do aluno e, de outro, a correção resolutiva ${ }^{3}$. As atividades de leitura também foram realizadas em quatro etapas: apresentação do texto e contextualização; uma primeira leitura, ora individual ora compartilhada, sem interrupções ou intervenções do professor; uma segunda leitura com intervenções, geralmente na forma de questionamentos, em que o professor procurava destacar algum aspecto linguístico ou temático; uma terceira etapa, em que o professor orientava discussões sobre aspectos discursivos, estilísticos, composicionais e temáticos, com ampla participação dos alunos.

Nas atividades de produção textual, os alunos foram orientados a escrever "relatos autobiográficos". Entendemos aqui "relato autobiográfico" como um texto curto, predominantemente narrativo, no qual podem ocorrer outros tipos de sequências textuais, sobretudo descritivas e dialogais, em que o enunciador narra, em primeira pessoa, um ou mais fatos supostamente vividos por ele. Neste caso, o pacto autobiográfico (LEJEUNE, 2008) ${ }^{4}$ pode ou não ocorrer. Ou seja, o texto pode ser lido como ficção ou realidade, conforme as escolhas feitas pelo autor e de acordo com pistas ou marcas presentes ou não ao longo do texto. Trata-se, por fim, de gênero textual flexível, com estruturas composicionais variadas, que se aproxima de vários gêneros textuais, como crônica autobiográfica, diário, relato de viagem, causo e conto.

Após a aplicação da sequência didática, analisamos os dados colhidos a partir de três enfoques: a relação entre discurso e identidade sociocultural; a aquisição de habilidades de leitura e escrita por meio das escritas da memória; a relação entre escritas da memória, letramento e autoria.

3 Sobre os modos de correção de textos na escola, ver RUIZ (2001).

4 Conceito formulado pelo teórico e crítico francês Philippe Lejeune (v. LEJEUNE, 2008), que consiste em uma espécie de acordo implícito entre o autor e o leitor, uma espécie de contrato de leitura baseado, sobretudo, na identificação entre autor, narrador e personagem. Tal identificação pode ocorrer de várias formas, e a mais óbvia é quando autor, narrador e personagens são identificados pelo mesmo nome. Outra forma de afirmar essa identificação é quando não se menciona o nome do personagem ao longo da narrativa, mas há indícios de várias ordens que levam o leitor a supor tal identificação. Este fenômeno gera, no horizonte de expectativa do leitor (JAUSS, 1994), a crença de que o livro trata de experiências reais vividas por uma pessoa real, que seria o autor da obra. O pacto autobiográfico, portanto, depende do leitor, que deve encarar a leitura não como o consumo de um objeto imaginário, mas como o consumo de um objeto que ele crê ser real. 
Linha D'Água (Online), São Paulo, v. 29, n. 1, p. 143-165, jun. 2016

Nas próximas seções deste artigo, vamos discutir aspectos concernentes aos primeiro e terceiro enfoques acima mencionados.

\section{Memória e identidade}

Quando o sujeito lembra o passado, ele o reconstrói segundo um ponto de vista, reconstrói um novo sentido de acordo com determinados valores e formas de ver o mundo. Ele representa o passado conforme crenças e valores construídos ao longo de sua experiência. Tais valores e crenças decorrem das relações do sujeito com o mundo e com a sociedade. Nesse sentido, a memória pode ser compreendida como uma construção sócio-histórica. Ao ressignificar o passado, o sujeito constrói avaliações e representações de si mesmo, do ser e estar no mundo, constrói uma identidade. Mas se a memória individual é atravessada pela memória coletiva e se constitui como espaço de construção de identidades, qual a fronteira entre o individual e o coletivo nesse processo? $\mathrm{Ou}$, posto de outra forma: a identidade seria individual ou coletiva?

Segundo Charaudeau (2015), "não há ato que realizemos, nem pensamento que exprimamos que não contenha o traço de nosso pertencimento à coletividade" (CHARAUDEAU, 2015, p. 15). Com efeito, se somos seres essencialmente sociais, uma vez que vivemos em grupo, todas as nossas ações e pensamentos se dão em relação aos outros. É por meio das trocas sociais que forjamos uma identidade. Nesse sentido, a identidade se constitui em um movimento entre o olhar de si sobre si e o olhar do outro sobre si.

Por meio dessas trocas ou atravessamentos que se constitui o que podemos chamar de identidade coletiva, uma vez que a identidade de um grupo não é a soma de identidades individuais. Nesse movimento de trocas e negociações, o indivíduo dá outro sentido a valores coletivos, os quais, ressignificados pelo indivíduo, voltam à sociedade, onde, por sua vez, ganham novas formas e significados. Ou seja, na identidade coletiva, "um mais um não são dois, mas um novo um que engloba ambos" (CHARAUDEAU, idem ibidem).

A identidade coletiva, portanto, não é um fenômeno que existe a priori, é uma construção que se constitui por meio de atos e pensamentos de indivíduos em um tempo e em um espaço historicamente determinados. Destarte,

É uma ilusão crer que nossa identidade repousa sobre uma entidade única, homogênea, uma essência que constituiria nosso substrato do ser: "não existe identidade 'natural' que nos seria imposta pela força das coisas. Não há senão estratégias identitárias, racionalmente conduzidas por atores identificáveis. Nós não estamos 
Linha D'Água (Online), São Paulo, v. 29, n. 1, p. 143-165, jun. 2016

condenados a permanecer reféns desses sortilégios" (Bayard, 1996). (CHARAUDEAU, op. cit., p. 17)

Desse modo, a identidade coletiva está relacionada a valores e crenças partilhadas, que podem, por sua vez, sofrer múltiplas influências, dependendo das mais diversas contingências históricas. Ou seja, é no devir que a identidade coletiva se constrói, no cotidiano das trocas simbólicas e das negociações de sentidos.

A identidade coletiva, assim compreendida, pressupõe, portanto, que os indivíduos que a constroem se sintam parte de um grupo. Como compreender o que faz com que nos sintamos pertencentes a um grupo e não a outro? Para resolver essa questão, Charaudeau (2015) se utiliza de um conceito que ele chama de "princípio da alteridade". Há como que um jogo entre o igual e o diferente. São, portanto, as semelhanças e dessemelhanças que nos fazem sentir pertencentes a um grupo e não a outro. Entretanto, para que tal jogo se constitua, o indivíduo precisa construir uma imagem de si e do outro, isto é, uma representação de si e do outro. Segundo Charaudeau (2015), “essas representações evidenciam imaginários coletivos que são produzidos pelos indivíduos que vivem em sociedade, imaginários esses que manifestam, por sua vez, valores por eles compartilhados, nos quais eles se reconhecem e que constituem sua memória identitária" (CHARAUDEAU, op. cit., p. 21).

Para compreender como se dá o processo de construção da identidade sociocultural por meio das escritas da memória no corpus da pesquisa - relatos autobiográficos escritos por alunos-, identificamos neles alguns temas ou eixos semânticos que, interligados, constroem um perfil identitário: revelam como esses alunos-autores compreendem o mundo e se posicionam na sociedade. Ou seja, tais temas ou eixos temáticos constroem um imaginário social constituído por crenças, valores, modos de percepção do espaço, do tempo e do corpo, ideologias e formas de situar-se no jogo das relações de poder.

Para analisar como esses eixos semânticos se associam e como constroem um imaginário compartilhado socialmente, recorremos aos conceitos de memória discursiva, interdiscurso e formação discursiva, de acordo com os pressupostos da Análise do Discurso. Segundo Orlandi (2001):

Em sua definição, o interdiscurso é o conjunto de dizeres já-ditos e esquecidos que determinam o que dizemos, que sustentam a possibilidade mesma do dizer. Para que nossas palavras tenham sentido é preciso que já tenham sentido. Esse efeito é produzido pela relação com o interdiscurso, a memória discursiva: algo falado antes, em outro lugar, e independentemente. Filiamo-nos a redes de sentidos em um gesto de interpretação, na relação com a língua e a história, e em que 
trabalham a ideologia e o inconsciente: "há um real constitutivamente estranho à univocidade lógica e um saber que não se transmite, não se aprende, não se ensina a que, no entanto, existe produzindo efeitos" (Pêcheux, 1990). (ORLANDI, 2001, p. 151).

Em consonância com tais pressupostos, levamos em conta as condições de produção do texto, a posição dos interlocutores e as formações discursivas a que se associam. O enunciado é visto, portanto, em sua historicidade e sua relação com as ideologias e as representações sociais que o atravessam, porquanto "a materialidade da ideologia é o discurso e a materialidade do discurso é a língua” (ORLANDI, op. cit., p. 157). De acordo com Orlandi (2001):

(...) Não há discurso sem sujeito e não há sujeito sem ideologia. Há, entre os diferentes modos de produção social, um modo de produção social específico que é simbólico. Há, pois, práticas simbólicas significando (produzindo) o social. A materialidade do simbólico assim concebido é o discurso. $\mathrm{O}$ discurso, concebido em sua materialidade simbólica, é efeito de sentidos entre locutores. Ele traz em si as marcas da articulação da língua com a história para significar. (...)

Quando dizemos que o discurso é efeito de sentidos entre locutores, estamos assim pensando o efeito produzido pela inscrição da língua na história, para significar, regida pelo mecanismo ideológico. Estamos, em decorrência, pensando a interpretação, pois a interpretação torna visível a relação da língua com a história. Não há sentido sem interpretação. (ORLANDI, op. cit., p. 154)

Compreendemos, dessa forma, que os sentidos de um texto não são estanques, pois dependem de uma série de negociações de sentido realizadas pelos sujeitos sociais no cotidiano das trocas simbólicas. Ao se fazer enunciador e ao se remeter ao passado, o sujeito-autor da escrita da memória "se ancora" em um e não em outro sentido (ou em um e não outro discurso). Conforme essa concepção,

não é no texto em si que estão (como conteúdos) as múltiplas possibilidades de sua leitura, é no espaço constituído pela relação do discurso e o texto, um entremeio, onde jogam os diferentes gestos de interpretação. Não se trata assim nem de marcas visíveis só na língua ou só ação do contexto: são relações estabelecidas a partir dessa articulação material fundamental, a do texto com o discurso. (ORLANDI, op. cit., p. 157) 
O texto, portanto, não se abre para todo e qualquer sentido, pois a relação entre o texto e o discurso está inscrita como possibilidade e potência nas singularidades de sua materialização linguística e do contexto historicamente determinado.

Mantendo-se nos limites desse enquadramento teórico, compreendemos a noção de ethos discursivo de uma forma diferente daquela compreendida e conceituada por Maingueneau. Nos vários ensaios deste autor, o conceito de ethos discursivo relaciona-se com "a imagem de si que o locutor constrói em seu discurso para exercer uma influência sobre seu alocutário" (CHARAUDEAU; MAINGUENEAU, 2014, p. 220). Esse conceito diz respeito aos mecanismos de persuasão. Entendemos o ethos discursivo a partir dos conceitos de memória discursiva e formação discursiva. Ou seja, compreendemos ethos discursivo como uma imagem de si que o locutor constrói a partir dos discursos e das ideologias a que este adere, conscientemente ou não, por meio da linguagem.

Destarte, identificamos, na análise dos textos, quatro temas recorrentes, que chamamos aqui, conforme acima exposto, de eixos semânticos ou temáticos: a nostalgia do espaço rural, algumas vezes em contraposição ou confronto com o espaço urbano; o espaço urbano identificado como o espaço da ascensão social (da "conquista", do "vencer na vida"); o ser e o estar no mundo, imbricados em campos semânticos relacionados com as ideias de luta, enfrentamento, sofrimento; a ideia de família, que, por sua vez, aparece ramificada em dois eixos - avós, mãe, pai e irmãos no passado rural/ marido ou esposa e filhos no espaço urbano. Cabe notar que este último eixo aparece vinculado a campos semânticos que se associam às ideias de conquista e construção ("construir família"). O espaço rural aparece relacionado a três eixos temáticos: trabalho; brincadeiras de infância; espaço rural em confronto com o espaço urbano.

No exemplo que se segue, o espaço rural está vinculado ao trabalho na roça e ao trato com os animais: "Eu e meu pai vivemos trabalhando para sustentar nossa Familia. Nós acordávamos cedo: Papai levantava primeiro para Fazer o café e Eu em seguida. Íamos ao curral para tirar o leite e, quando o sol raiava, pegávamos o cavalo e Iamos para a cidade levando o leite" 5 .

Fenômeno semelhante ocorre no fragmento que se segue. Note-se o uso da exclamação, como a indicar uma apreciação positiva do que se relata: “- comecei trabalhar muito cedo, ajudando meu pai na roça e pastorando o gado!”.

5 As transcrições aqui apresentadas procuraram ser fiéis (na medida do possível) ao modo como o aluno escreveu. Desse modo, foram mantidas a ortografia, a acentuação e a pontuação do texto original. Os nomes dos alunos foram grafados apenas com as iniciais, em caixa alta. 
Em outro texto, o enunciador trata da mesma questão, aqui associada ao modo como a imagem do espaço rural se processa na memória: "Ainda tenho vivo na memória que haviam grandes roçados de meu pai eu ainda era muito criança com idade de cinco anos mas ainda lembro que se formava aquele dia tão lindo muito quente (...)" [grifos nossos].

As brincadeiras de infância aparecem associadas a brinquedos rústicos e a hábitos culturais pouco ou nada presentes no espaço urbano. No próximo excerto, por exemplo, faz-se referência a um tipo de brincadeira próprio do espaço rural:

Dos meus 10 a 11 anos eu e meus irmãos brincava-mos de burrincas nos cortava-mos a madeira e nos mesmos faziamos a burrinca colocava-mos carvão pra quando rodasse fazer barrulho air 2 montavam e 1 rodava levava cada queda que chegava a gemer quando levantava-mos montavam novamente chegava a ficar tonto nem equilibrava de pé (...).

Em alguns textos, as brincadeiras de infância se associam ao contato com a família e com a natureza: "A gente se dívertia bastante no sitío com a familia e tomava banho de açude e subia no pé de manga e de goiaba”.

Em um dos textos, as brincadeiras de infância no espaço rural são confrontadas com as brincadeiras infantis no espaço urbano, com uma apreciação positiva daquelas em detrimento destas últimas: "Na rua em que eu morava havia muito lugar para se divertir, mas não era em cinema, Shopping ou danceterias, era no terreiro onde eu brincava de pula corda, pega-pega, esconde-esconde ou até de escorregar no barranco".

Enfim, nesses fragmentos textuais, percebe-se a construção de um ethos profundamente identificado com o espaço rural. O espaço da memória vai construindo uma identidade sociocultural que se associa a hábitos e formas de compreensão do mundo próprios do espaço rural.

O eixo temático espaço urbano como espaço da ascensão social aparece geralmente associado a dois campos semânticos: conquista e vencer na vida. Esses dois campos de significação reproduzem discursos muito difundidos na cultura urbana: meios de comunicação, igrejas, a chamada literatura de autoajuda. Nesse sentido, o discurso reproduz o interdiscurso e se associa a uma determinada formação discursiva.

Veja-se, a esse respeito, este fragmento de um dos textos que compõe o corpus aqui analisado:

- Aos 17 anos conquistei o meu primeiro emprego no qual trabelhei por seis anos, em 2003 voltei para São Paulo, dessa vez sozinho mais já com emprego certo, onde 
Linha D'Água (Online), São Paulo, v. 29, n. 1, p. 143-165, jun. 2016

continuo até hoje! No mesmo ano conheci minha esposa nos casamos e contruimos à nossa família

-Hoje tenho 2 filhos um de 8 e outro de 4 anos, conquistei minha casa própria, subí de cargo na empresa e luto por uma vida melhor pra mim e pra minha família.

Pois acredito que podemos conquistar muitas coisas quando temos força de vontade. [grifos nossos]

Note-se que o verbo "conquistar" aparece três vezes no excerto. Vale observar o uso da exclamação na frase destacada, que pode ser compreendida como indicação de surpresa (contrariamente ao que seria mais esperado, permaneci no mesmo emprego) ou de uma apreciação positiva de si mesmo (continuo até hoje neste emprego porque sou um funcionário esforçado e aplicado). Esta última forma de compreender o uso da exclamação se associa a outros elementos do texto: às orações "subi de cargo na empresa e luto por uma vida melhor para mim e para minha família" (grifos nossos) e ao parágrafo final ("Pois acredito que podemos conquistar muitas coisas quando temos força de vontade"). Note-se, com relação às orações destacadas, que elas são conectadas pela conjunção aditiva "e", a qual, no período em questão, transcende os sentidos de acréscimo ou contiguidade, usualmente atribuídos a esse conector, sugerindo um sentido concessivo que reforça a ideia de esforço: subi de cargo e, ainda assim, continuo lutando por uma vida melhor ou embora eu já tenha subido de cargo, não me dou por satisfeito e continuo lutando por uma vida melhor. Quanto ao último parágrafo, cabe notar que ele é marcado por vários aspectos linguísticos que potencializam as ideias de esforço e conquista: é o único parágrafo antecedido por espaçamento (os outros são antecedidos por travessão); é iniciado pelo conector argumentativo de sentido explicativo "pois", que parece referir-se a todo o texto (não apenas à oração ou ao período anterior), como se o que é dito no parágrafo explicasse toda a trajetória de vida relatada; o parágrafo é modalizado pela forma verbal "acredito", indicando que o enunciado é apresentado como uma crença, ou, em outras palavras, como uma forma de compreender o ser e o estar no mundo. Ademais, todos esses elementos aqui destacados neste último parágrafo reforçam o ethos que é construído ao longo de todo o texto, por meio do qual o enunciador se apresenta como um exemplo a ser seguido. Desse modo, embora estejamos utilizando o conceito de ethos discursivo em uma acepção diferente da de Maingueneau (conforme acima discutido), nesse caso cabe a concepção deste autor, uma vez que parece evidente a intenção, por parte desse enunciador, de legitimar-se e erigir-se como modelo por meio da imagem que constrói de si: "a prova pelo ethos consiste em causar boa impressão pela forma como se constrói o discurso, a dar uma 
Linha D'Água (Online), São Paulo, v. 29, n. 1, p. 143-165, jun. 2016

imagem de si capaz de convencer o auditório, ganhando sua confiança" (MAINGUENEAU, 2015, p. 13).

Com traços semânticos um pouco distintos, mas também associada à ideia de conquista, aparece, no corpus, a palavra "oportunidade":

E Fui para a capital onde comecei a trabalhar, como Eu tinha porco Estudo fui trabalhar na obra de ajudante de pedreiro Passei um ano e tive uma oportunidade de trabalhar como encanador e passei mais quartro anos e tive outra oportunidade para encarregado de Hidráulica.

Esta maneira de compreender o ser e o estar no mundo reproduz determinados discursos muito difundidos nos meios de comunicação e se ancora em uma formação discursiva em que trabalho e esforço são associados a ascensão social e acesso a bens de consumo.

O eixo temático luta/enfrentamento/sofrimento se associa ao eixo temático analisado anteriormente (da ascensão social e da conquista), relacionando-se, sobretudo, com dois aspectos: a morte de familiares, principalmente pais ou avós, e a consequente necessidade de trabalhar para sustentar os irmãos mais novos; a perda da infância ou da adolescência.

Veja-se, como exemplo do primeiro aspecto, este fragmento:

Mas uma coisa muito triste que marcou minha infância e que também me ensinou a viver, foi a morte do meu pai, ele era um homem forte, trabalhador e amável com minha mãe.

Deste dia pra cá, não sei lembrar dele sem lembrar também do sofrimento que passamos e das dificuldades financeiras que enfrentamos. [grifos nossos]

Essas mesmas ideias de luta, enfrentamento e sofrimento aparecem também associadas, não à morte do pai, mas a sua ausência. E, no exemplo que se segue, associadas ao preconceito:

Eu ainda era pequena, tinha seis anos, quando comecei a conhecer as dificuldades. Eramos em três, minha mãe, meu irmão e eu. Cresci em meio a, tanto preconceito, nós não convivíamos com o nossos pais. O pai do meu irmão parecia fugir de nós, já eu nunca soube quem é o meu pai biologico. Mas minha mãe guerreira lutava só sem ajuda de nenhum familiar, ela pagava aluguel e trabalhava tanto que, quando chegava em casa já era tarde, pegava nossos cadernos para ver as notas, limpava a casa, e lavava as roupas. [grifos nossos] 
Como esses fragmentos demonstram, as ideias de luta/ enfrentamento/ sofrimento se associam intrinsecamente à ideia de conquista, de tal forma que esses dois eixos temáticos se reforçam mutuamente e são determinantes para a construção de um ethos e de uma forma de compreender a realidade, constituindo, dessa forma, uma identidade sociocultural imbricada em um espectro ideológico que associa luta e sofrimento a sobrevivência, ascensão social e sucesso individual (exatamente assim, em escala ascendente), como ilustra este outro trecho:

Às vezes lembro, quando eu era criança, não tinha brinquedos e queria muito uma boneca da Estrela e, quando finalmente ganhei, não tive tempo de brincar com ela.

Entretanto, não me arrependo, o importante é que hoje eu estou buscando, através do CIEJA, uma forma de atingir os meus objetivos, que é fazer o meu sonho se tornar realidade. [grifos nossos]

Como já foi exposto, o eixo temático família ramifica-se e aparece como duas vertentes de um mesmo rio: de um lado, pais, avós e irmãos associados ao passado e ao espaço rural; de outro, esposa/marido e filhos associados ao presente e ao espaço urbano. Essa última característica aparece relacionada com a ideia de construção ("construir uma família).

Como ilustração da primeira vertente, tome-se como exemplo o trecho que se segue: "Filho de Familía Pobre, meu pai e minha Mãe trabalhavam na lavoura para criar meus quartro [sic] irmão, Nós fomos criados em um sitio chamado Jácaré, onde nós Brincávamos com meus irmão". A outra vertente, por sua vez, aparece neste exemplo: "Em 1971. Eu mudei para São Paulo. Aode construi minha familia e a ate hoje. Eu vivo com a família" [grifos nossos].

Neste outro trecho, de um texto já comentado, a ideia de "construir uma família" se vincula às ideias de luta e de conquista:

- Aos 17 anos conquistei o meu primeiro emprego no qual trabelhei por seis anos, em 2003 voltei para São Paulo, dessa vez sozinho mais já com emprego certo, onde continuo até hoje! No mesmo ano conheci minha esposa nos casamos e contruimos à nossa família

- Hoje tenho 2 filhos um de 8 e outro de 4 anos, conquistei minha casa própria, subí de cargo na empresa e luto por uma vida melhor pra mim e pra minha família.

Como se observa nesse último exemplo, os quatro eixos temáticos aqui descritos se imbricam, um potencializa o outro e, intrinsecamente associados, 
Linha D'Água (Online), São Paulo, v. 29, n. 1, p. 143-165, jun. 2016

ancoram-se em uma determinada formação discursiva, construindo um ethos discursivo e uma identidade sociocultural associados às seguintes ideias, assim dispostas e relacionadas: espaço rural $\rightarrow$ sofrimento $\rightarrow$ perda $\rightarrow$ migração $\rightarrow$ espaço urbano $\rightarrow$ luta $\rightarrow$ esforço $\rightarrow$ conquista $\rightarrow$ ascensão social. Nesse sentido, memória e interdiscurso se associam na construção de uma memória coletiva e, por extensão, de uma identidade sociocultural. Essa maneira de ver e de entender o mundo, como se constata, está também associada à busca da escolaridade e do conhecimento formal. Ocorre, portanto, um processo de desenraizamento, no qual se inserem a escola e a cultura letrada. Não obstante, e aí reside a importância das escritas da memória como prática escolar de letramento, o resgate das brincadeiras da infância e dos hábitos e costumes do espaço rural inverte a lógica desse processo e promove o reenraizamento. Nesse processo, cultura oral e cultura letrada se entrecruzam e se associam por meio do discurso da memória.

\section{Escritas da memória e autoria}

Um dos objetivos da aplicação da sequência didática apresentada era que os alunos se constituíssem como sujeitos-autores de seus textos, ou seja, que eles adquirissem habilidades de escrita que lhes permitissem ser e agir por meio da linguagem. Foi o que ocorreu ao longo do processo ensino-aprendizagem, uma vez que, nas atividades de reescrita, os alunos reorganizaram seus textos, tornando-os mais claros, reorganizaram em parágrafos textos anteriormente dispostos em um único bloco, acrescentaram informações e suprimiram outras, acrescentaram conectores argumentativos, substituíram uma palavra por outra, alteraram a pontuação. Quando isso ocorre, o aluno está agindo e sendo por meio da linguagem; está, portanto. constituindo-se como sujeito-autor.

Não obstante, o conceito de "autoria" é um tanto controvertido e comporta várias concepções. Algumas dessas concepções se baseiam em critérios subjetivos; outras, por sua vez, baseiam-se no conceito de "correção gramatical"; há ainda aquelas que se utilizam dos conceitos de inteligibilidade e aceitabilidade; há, por fim, conceitos que tomam como base a noção de "estilo", desconsiderando, entretanto, a historicidade do texto. Alguns conceitos, como os de Foucault (2002) e de Maingueneau $(2010)^{6}$ também são insuficientes para que se possa compreender

6 Para Foucault (2002), a noção de "autor" se relaciona à noção de "obra". Segundo essa concepção, um autor se constitui na medida em que podemos associá-lo a uma obra. Nesse sentido, as noções de "autor" e de "escritor" não se confundem: o "escritor" seria o indivíduo que escreve; o "autor", por sua vez, estaria relacionado a um conjunto de textos associados ao 
Linha D'Água (Online), São Paulo, v. 29, n. 1, p. 143-165, jun. 2016

qual é a fronteira entre autoria e não-autoria em textos escolares, uma vez que dizem respeito à imagem de autor historicamente construída e não a aspectos estilísticos ou composicionais por meio dos quais se possa atribuir o estatuto de "autor" a um produtor de texto. Como uma possível solução para esta questão, Possenti (2002) afirma que um produtor de texto se constitui como autor quando assume (conscientemente ou não) duas atitudes: dar voz a outros enunciadores e manter distância com relação ao próprio texto. A primeira atitude ocorre quando o texto aciona o interdiscurso e dialoga com outros pontos de vista, atribuindo-os a outros enunciadores; a segunda atitude, por sua vez, ocorre quando o produtor do texto se posiciona com relação ao que diz e com relação ao que os outros dizem. Essa segunda atitude ocorre, por exemplo, quando o texto aciona mecanismos metadiscursivos e comenta as próprias posições. Há inúmeros mecanismos linguísticos por meio dos quais o enunciador se posiciona com relação ao que diz, por exemplo, a escolha dos verbos dicendi ou o uso de um adjetivo mais marcado no lugar de outro menos marcado semanticamente. Assim, a proposta de Possenti (2002) resgata o conceito de "estilo" (que diz respeito à singularidade, a recursos da língua agenciados de forma pessoal), redimensionando-o, pois, para o autor, "o apelo a tais recursos só produz efeitos de autoria quando agenciados a partir de condicionamentos históricos, pois só então fazem sentido" (POSSENTI, op. cit., p. 121).

Essa proposta é, portanto, muito produtiva para se possa estabelecer, no que diz respeito a textos escolares, uma possível fronteira entre o que é autoral e o que

seu nome, considerando os mais diversos critérios, como a responsabilidade sobre o que publica e um determinado projeto que se possa extrair desse conjunto de textos. A noção de "autor", vista dessa forma, é considerada de acordo com traços históricos e culturais variáveis, uma vez que a relação entre "obra" e "autor" depende em grande parte do modo como são compreendidos os vários discursos postos em circulação em épocas ou culturas distintas. O conceito de Foucault, portanto, não diz respeito aos textos produzidos por alunos, uma vez que estes, em sua maioria, ainda não possuem uma "obra" (de acordo com o conceito que Foucault atribui a este termo). Maingueneau (2010) amplia o conceito de Foucault (2002), propondo três instâncias de "autoria": a de "garante", aquele que assume a responsabilidade por um texto, associando-o a seu nome; a de "autor-ator", aquele que, de alguma forma, ocupa-se da produção de textos, tem vínculos com editoras, jornais, etc.; a de "auctor", aquele cujo nome se associa a uma obra ou a um conjunto de textos que constituem um "Thesaurus literário". De acordo com tal pressuposto, para que um indivíduo se constitua como "auctor", é necessário que outros o instituam como tal, por meio de vários enunciados sobre ele e sua obra, conferindo-lhe uma "imagem de autor". Portanto, segundo tal concepção, alunos-produtores de textos pertenceriam à primeira instância proposta por Maigueneau (2010), uma vez que, segundo este autor, "se por definição todo texto tem um garante, apenas uns poucos indivíduos alcançam o estatuto de 'auctor'" (MAINGUENEAU, 2010, p. 142). 
Linha D'Água (Online), São Paulo, v. 29, n. 1, p. 143-165, jun. 2016

não o é. Mas acrescentamos uma terceira característica que pode ser vista como indício de autoria em textos de alunos: a capacidade que tem um texto de reconfigurar ou redimensionar as características do gênero a que pertence, uma vez que, dessa forma, o produtor de textos não reproduz esquemas estanques, ele age, cria, recria, repensa. Desse modo, associamos o conceito de autoria ao de agência. Partindo dessa concepção, entendemos que os "gêneros são não somente formas textuais, mas também formas de vida e de ação" (BAZERMAN, 2011, p. 19). Porquanto "a escrita está profundamente associada a valores de originalidade, personalidade, individualidade - com razão, porque nos fornece os meios pelos quais deixamos traços de nossa existência, nossas condições de vida, nossas ações e nossas intenções" (BAZERMAN, op. cit., p. 11). Entende-se, dessa maneira, que "a abordagem social de gênero transforma-o em uma ação social e assim em uma ferramenta de agência" (BAZERMAN, op. cit., p. 19).

Apresentamos a seguir um texto produzido por uma aluna no contexto do processo de ensino-aprendizagem a que nos referimos, no qual podemos vislumbrar alguns traços de autoria, uma vez que ele transcende o modelo arquetípico do gênero e nele o enunciador aciona outras vozes e se posiciona com relação ao que diz e ao que os outros dizem ( $c f$. POSSENTI, op. cit.). Cabe notar que, diferentemente de outros textos que compõem o corpus aqui analisado, em que o locutor se limita a relatar eventos de sua vida em uma ordem cronológica, neste texto, o enunciador/narrador em $1^{\text {a }}$ pessoa se apresenta inteiro, revelando sentimentos e refletindo sobre eles como se estivesse escrevendo um diário íntimo. Nesse movimento, o enunciador vasculha a memória, relaciona o passado com o presente, questiona-se, revela sentimentos contraditórios, reaviva imagens e sensações há muito esquecidas, reflete sobre seus sonhos e frustrações. Vejamos o texto:

\section{Só Lembranças e nada mais}

Eu nasci em 1975 em uma cidade chamada Escada. Minha mãe me deu à luz em casa e cresci em um bairro em que havia muitas crianças da mesma idade.

Na rua em que eu morava havia muito lugar para se divertir, mas não era em cinema, Shopping ou danceterias, era no terreiro onde eu brincava de pula corda, pega -pega, esconde-esconde ou até de escorregar no barranco.

Eu tive uma infância maravilhosa, amava comer as frutas que tinha no quintal da minha casa, pegava água no poço e tirava leite das cabras para o café da manhã. Sinto saudades daquele tempo, eu era feliz e não sabia, mas lá eu recebi as informações que preciso para viver, que foi a educação que minha mãe me deu.

E o fato de ir para a escola, isto foi fundamental para ampliar os meus conhecimentos. 
Mas uma coisa muito triste que marcou minha infância e que também me ensinou a viver, foi a morte do meu pai, ele era um homem forte, trabalhador e amável com minha mãe.

Deste dia pra cá, não sei lembrar dele sem lembrar também do sofrimento que passamos e das dificuldades financeiras que enfrentamos.

Mas tudo isto serviu de aprendizado.

Meu irmão, com 15 anos, foi trabalhar em uma tecelagem.

Eu, com 13, fui trabalhar em casa de familia e minha irmã caçula, 2 anos depois, foi trabalhar em uma granja.

Todos aprendemos uma profissão, aprendemos a encarar todas as situações e hoje eu posso passar as minhas experiências para meus filhos.

Às vezes lembro, quando eu era criança, não tinha brinquedos e queria muito uma boneca da Estrela e, quando finalmente ganhei, não tive tempo de brincar com ela.

Entretanto, não me arrependo, o importante é que hoje eu estou buscando, através do CIEJA, uma forma de atingir os meus objetivos, que é fazer o meu sonho se tornar realidade.

Quando criança, imaginava como seria a minha vida adulta, tinha medo de pensar, mas era inevitável porque sempre ouvia os comentarios sobre a meninas da minha idade que se perdiam.

Esta palavra me dava arrepios.

Finalmente, quando cheguei à adolescência, passei por uma situação difícil.

A falta de informação, a ignorância da parte da minha mãe, e um pouco do incentivo de terceiros, me levou a conhecer mais cedo a vida adulta.

Fui mãe com apenas 15 anos e então pensei: e agora, como vou me sair desta? Que atitudes vou tomar?

Tinha medo de continuar sendo tratada como criança, por isso eu fui tão submissa ao meu companheiro.

Antes que meu filho completasse 2 meses de idade, eu vim morar aqui nesta cidade linda que é São paulo e aqui tantas coisas aconteceram, foi tanto sofrimento que não lembrava mais de me preocupar de como seria a minha fase adulta.

Às vezes, quando estou com saudade da minha familia, eu lembro de minha infância.

Outro dia lembrei que, junto a minha irmã, brincavamos de fazer comida com as plantas.

As bonecas eram espigas de milho ainda com cabelos e ficavamos encantadas com os diferentes tipos que achavamos.

Também tive o prazer de ter a minha mãe na brincadeira, ela fazia animais de barro vermelho e, quando acabava a brincadeira, guardávamos os bichinhos com muito carinho e isto ficou na memoria. 
Linha D'Água (Online), São Paulo, v. 29, n. 1, p. 143-165, jun. 2016

Amava correr no pasto enquanto as cabras se alimentavam e de subir no pé de carambola.

Estas lembranças me vêm à mente trazendo junto a saudade e me fazendo pensar que eu queria voltar no tempo e consertar o passado, mas não tem o que fazer, então me preparo, o jeito é viver.

Viver um dia de cada vez, viver com firmeza, fazendo o que sei: Que é amar a vida, amar o próximo, a natureza; amar a Deus com certeza, com fé e esperânça, como se fosse ainda uma criança.

Esta sou eu. Meu nome é Adriana, moro há 20 anos em São Paulo.

Sou casada, tenho 3 filhos e sou feliz.

O traço de autoria já se apresenta no título ("Lembranças e nada mais"), o qual antecipa certa melancolia que vai se fazer presente em quase todo o texto. $\mathrm{O}$ tom reflexivo e questionador, de que todo o texto vai se revestir, surge no segundo e no terceiro parágrafos, em que o enunciador/narrador questiona e redimensiona o presente a partir de lembranças da infância no meio rural:

$\mathrm{Na}$ rua em que eu morava havia muito lugar para se divertir, mas não era em cinema, Shopping ou danceterias, era no terreiro onde eu brincava de pula corda, pega-pega, esconde-esconde ou até de escorregar no barranco.

Eu tive uma infância maravilhosa, amava comer as frutas que tinha no quintal da minha casa, pegava água no poço e tirava leite das cabras para o café da manhã.

Com efeito, há, nessa sequência, vários recursos linguísticos que potencializam a reflexão acerca do presente, a partir de dados do passado: o conector argumentativo "mas", de valor opositivo, acompanhado pelo advérbio de negação ("mas não era"); o quantificador "muito" ("muito lugar"); o adjetivo "maravilhosa" (que tem um sentido superlativo, uma vez que "maravilhoso" é muito mais do que "bom"); o verbo "amar", em "amava comer as frutas" (que também tem sentido superlativo, visto que "amar" é muito mais do que "gostar"); o pronome possessivo "minha" ("minha casa"). Todos esses elementos reforçam a apreciação positiva do passado rural em detrimento do presente. Nesse mesmo sentido pode ser compreendido o uso do conector "mas", no quarto parágrafo, aparentemente inadequado, já que não parece haver oposição entre as informações por ele conectadas: o que se opõe, em realidade, é o mundo infantil, apreciado positivamente nos parágrafos anteriores, e as dificuldades da vida, o que está subentendido nos substantivos de sentido genérico "informações" e "educação" ("mas lá eu recebi as informações que preciso para viver, que foi a educação que minha mãe me deu"). Note-se que toda essa reflexão 
Linha D'Água (Online), São Paulo, v. 29, n. 1, p. 143-165, jun. 2016

se tinge de um tom melancólico e confessional: "sinto saudades daquele tempo, era feliz e não sabia”.

$\mathrm{Na}$ continuidade do texto, outro emprego do "mas" reforça a oposição entre a infância feliz e o que se passou depois: "Mas uma coisa muito triste que marcou minha infância e que também me ensinou a viver, foi a morte do meu pai, ele era um homem forte, trabalhador e amável com minha mãe".

Note-se que a associação entre aprendizagem e dor prossegue: "e que também me ensinou a viver". Essa mesma associação é reforçada adiante: "mas tudo isso serviu de aprendizado". É o que se percebe ainda em outro trecho: "Todos aprendemos uma profissão, aprendemos a encarar todas as situações e hoje eu posso passar as minhas experiências para os meus filhos".

O tom reflexivo e confessional, à maneira de um diário íntimo, por meio do qual o enunciador procura compreender seus sentimentos do passado e do presente, evidencia-se, por exemplo, nos fragmentos que se seguem:

Às vezes lembro, quando eu era criança, não tinha brinquedos e queria muito uma boneca da Estrela e, quando finalmente ganhei, não tive tempo de brincar com ela.

Quando criança, imaginava como seria a minha vida adulta, tinha medo de pensar, mas era inevitável porque sempre ouvia os comentarios sobre a meninas da minha idade que se perdiam.

Esta palavra me dava arrepios.

O sentir/refletir se sobrepõe ao narrar/relatar. Por isso, as sequências narrativas são pontuadas por reflexões. Também por isso são recorrentes no texto verbos como "imaginar", "lembrar", "pensar", "sentir", "amar", "arrepender-se”, assim como os substantivos "lembrança", "saudades", "memória". Ainda nesse sentido, notem-se certas modalizações, como "foi fundamental" e "o importante é que". Ou seja, memória e linguagem resgatam sentimentos e sensações do passado e permitem que o enunciador reflita sobre suas experiências. $\mathrm{O}$ passado se faz presente e ganha novos sentidos por meio do discurso da memória. É o que ocorre em outro trecho, em que o enunciador/narrador reflete sobre as razões que o levaram a agir de determinada forma e, por extensão, questiona valores, põe em dúvida a educação que recebeu e reflete sobre as relações familiares:

Finalmente, quando cheguei à adolescência, passei por uma situação difícil.

A falta de informação, a ignorância da parte da minha mãe, e um pouco do incentivo de terceiros, me levou a conhecer mais cedo a vida adulta. 
Linha D'Água (Online), São Paulo, v. 29, n. 1, p. 143-165, jun. 2016

Fui mãe com apenas 15 anos e então pensei: e agora, como vou me sair desta? Que atitudes vou tomar?

As reminiscências do passado surgem no texto sem uma ordem determinada e de acordo com os movimentos da memória, de tal modo que se repetem, vão e voltam, sem seguir a ordem cronológica dos fatos. Essa característica, que poderia parecer uma deficiência do texto, torna-o mais atraente, pois cria uma intimidade com o leitor, uma relação de empatia e confiança, como se estivesse a contar segredos a um amigo.

Desse modo, o tom confessional constrói um ethos discursivo carregado de afetividade e redimensiona o gênero. Por meio do discurso da memória, o enunciador/narrador se faz sujeito-autor, é e age por meio da linguagem, o que confirma a concepção de Bazerman (2011), segundo a qual "a escrita nos permite uma semiprivacidade para enfrentar nossos pensamentos, memórias, emoções, como também nossos desejos para a criação de uma presença no mundo" (BAZERMAN, op. cit., p. 11).

Portanto, no texto apresentado, memória, agência e autoria se associam e, desta forma, o enunciador constitui-se como sujeito-autor que se posiciona e negocia sentidos no jogo das ideologias e das relações de poder.

\section{Conclusão}

O maior problema do professor na Educação de Jovens e Adultos é lidar com a heterogeneidade e com a multiplicidade de saberes e de modos de apreensão da realidade. Os alunos chegam à escola com níveis muito variados de letramento e com um saber forjado por outros sistemas de cognição e de compreensão do mundo. Tal fenômeno, como se pôde constatar neste artigo, está intimamente relacionado com diferenças socioculturais. Esse talvez seja um dos grandes obstáculos encontrados pelos educadores na Educação de Jovens e Adultos, pois, de acordo com Street (2014),

(...) a transferência de letramento de um grupo dominante para aqueles que até então tinham pouca experiência com a leitura e a escrita implica muito mais do que simplesmente transmitir algumas habilidades técnicas, superficiais. Ao contrário, para aqueles que recebem o letramento novo, o impacto da cultura e das estruturas político-econômicas daqueles que o transferem tende a ser mais significativo do que o impacto das habilidades técnicas associadas à leitura e à escrita. As mudanças de significado associadas a tais transferências se localizam em níveis epistemológicos profundos, levantando questionamentos sobre o que 
Linha D'Água (Online), São Paulo, v. 29, n. 1, p. 143-165, jun. 2016

é a verdade, o que é conhecimento e quais são as autênticas fontes de autoridade. (STREET, 2014, pp. 30-31)

Portanto, o grande desafio para professores e pesquisadores é encontrar um meio de lidar com a diversidade sociocultural de modo a torná-la um fator positivo, que favoreça a aprendizagem e que permita o compartilhamento de experiências e de maneiras diferentes de ser, estar e agir no mundo. Do contrário, a aprendizagem escolar pode constituir-se como mais um dos instrumentos de assujeitamento e de opressão.

Nesse sentido, o conceito de agência, associado ao aprender/ler/escrever, e o trabalho com as escritas da memória configuram-se como importantes instrumentos pedagógicos, capazes de tornar a aprendizagem escolar um instrumento de emancipação e de empoderamento de grupos sociais dominados política e economicamente.

\section{Referências}

BAZERMAN, C. Gênero, Agência e Escrita. São Paulo: Cortez, 2011.

BOSI, E. Memória e Sociedade: lembranças de velhos. São Paulo: EDUSP, 1987.

CHARAUDEAU, P. Identidade linguística, identidade cultural: uma relação paradoxal. In: LARA, G. P.; LIMBERTI, R. P. (orgs.). Discurso e (des)igualdade social. São Paulo: Contexto, 2015, pp. 13-29.

CHARAUDEAU, P.; MAINGUENEAU, D. Dicionário de Análise do Discurso. São Paulo: Contexto, 2014.

FOUCAULT, M. O que é um autor? Trad. A. F. Cascais e Edmundo Cordeiro. Portugal: Veja Editora, 2002.

FREIRE, P. Pedagogia da Autonomia: saberes necessários à prática educativa. São Paulo: Paz e Terra, 2002.

JAUSS, H. R. História da literatura como provocação à teoria literária. São Paulo: Ática, 1994.

KLEIMAN, A. Processos identitários na formação profissional. O professor como agente de letramento, in: CORRÊA, M.L.Gs; BOCH, F. (orgs.). Ensino de lingua: representação e letramento. Campinas: Mercado de letras, 2006, pp. 75-91. 
Linha D'Água (Online), São Paulo, v. 29, n. 1, p. 143-165, jun. 2016

LEJEUNE, P. O pacto autobiográfico. In: NORONHA, J. M. G. (org.). De Rousseau à Internet. Belo Horizonte: UFMG, 2008.

MAINGUENEAU, D. Doze conceitos em análise do discurso. São Paulo: Parábola, 2010.

A propósito do ethos. In: MOTTA, A. R.; SALGADO, L. (orgs). Ethos discursivo. São Paulo: Contexto, 2015, pp. 11-29.

MARCUSCHI, L. A. Gêneros textuais: definição e funcionalidade. In: DIONISIO, A. P.; MACHADO, Anna Rachel; BEZERRA, Maria Auxiliadora (orgs.). Gêneros textuais छ ensino. São Paulo: Parábola, 2010, pp. 19-38.

ORLANDI, E P. Os efeitos de leitura na relação discurso/texto. In: VALENTE, A. (org.). Aulas de Português: perspectivas inovadoras. Petrópolis: Vozes, 2001, pp. 151-158.

POSSENTI, S. Indícios de autoria. In: Perspectiva (revista do Centro de Ciência da Educação). Florianópolis, v. 20, n.01, 2002, pp. 105-123.

RUIZ, E. Como se corrige redação na escola. São Paulo: Mercado de Letras, 2001.

SOUSA, B. de O. A Memória como Elemento de Construção de uma Identidade Cultural, disponível em www.congressohistoriajatai.org/anais2008/doc. Acesso em 12/10/2015.

STREET, B. Letramentos sociais: abordagens do letramento no desenvolvimento, na etnografia e na educação. São Paulo: Parábola, 2014.

Recebido: 01/02/2016

Aprovado: 21/05/2016 